mediastudies.press • Social Media \& the Self: An Open Reader

\title{
Eat Me, Drink Me, Like Me
}

\section{Tara Isabella Burton}

Published on: Jan 01, 2020

License: Creative Commons Attribution-NonCommercial 4.0 International License (CC-BYNC 4.0). 
IN FEBRUARY OF 2017, Shane Patrick Boyle told us all a story. Shane, the affable founder of Zine Fest Houston, tweeted a link to his one hundred thirty-six followers, sharing with them a GoFundMe campaign to cover his medical costs. Shane, a Type 1 diabetic, had recently returned from Texas to Arkansas to care for his mother. In so doing, he'd given up an arrangement he'd made with a local clinic to get regular, affordable insulin. So he asked the public for money: $\$ 750$, to be exact.

Shane's tweet got minimal engagement. It wasn't enthrallingly written-just a poorly formatted link to the GoFundMe page, along with the relatively anodyne explanation: "I'm raising money for Insulin for Next Month. Click to Donate."

When Shane died of complications from diabetes a few weeks later, the GoFundMe was fifty dollars short. Shane had rationed his insulin, his cousin said on another GoFundMe campaign to cover the funeral costs. Although the original GoFundMe page is gone, Shane's tweet is still up. After three years, it has garnered just 53 likes....

$$
\text { continue reading }
$$

\section{OUTBOUND LINK}

“Eat Me, Drink Me, Like Me" (Tara Isabella Burton, The New Atlantis, Winter 2020)

FREE ACCESS 